Review

\title{
Risk assessment in submarine outfall projects: The case of Portugal
}

\author{
Ana Mendonça ${ }^{\mathrm{a}, *}$, Miguel Ángel Losada ${ }^{\mathrm{b}}$, Maria Teresa Reis ${ }^{\mathrm{a}}$, Maria Graça Neves ${ }^{\mathrm{a}}$ \\ a Laboratório Nacional de Engenharia Civil, DHA-NPE, Av. Brasil 101, 1700-066 Lisbon, Portugal \\ ${ }^{\mathrm{b}}$ Universidad de Granada, CEAMA, Avda. del Mediterráneo 5, 18006 Granada, Spain
}

\section{A R T I C L E I N F O}

\section{Article history:}

Received 2 January 2012

Received in revised form

27 November 2012

Accepted 6 December 2012

Available online

\section{Keywords:}

Submarine outfalls

Risk assessment

Limit states

Failure modes

\begin{abstract}
A B S T R A C T
Submarine outfalls need to be evaluated as part of an integrated environmental protection system for coastal areas. Although outfalls are tight with the diversity of economic activities along a densely populated coastline being effluent treatment and effluent reuse a sign of economic prosperity, precautions must be taken in the construction of these structures. They must be designed so as to have the least possible impact on the environment and at the same time be economically viable. This paper outlines the initial phases of a risk assessment procedure for submarine outfall projects. This approach includes a cost-benefit analysis in which risks are systematically minimized or eliminated. The methods used in this study also allow for randomness and uncertainty. The input for the analysis is a wide range of information and data concerning the failure probability of outfalls and the consequences of an operational stoppage or failure.

As part of this risk assessment, target design levels of reliability, functionality, and operationality were defined for the outfalls. These levels were based on an inventory of risks associated with such construction projects, and thus afforded the possibility of identifying possible failure modes. This assessment procedure was then applied to four case studies in Portugal. The results obtained were the values concerning the useful life of the outfalls at the four sites and their joint probability of failure against the principal failure modes assigned to ultimate and serviceability limit states. Also defined were the minimum operationality of these outfalls, the average number of admissible technical breakdowns, and the maximum allowed duration of a stoppage mode. It was found that these values were in consonance with the nature of the effluent (tourist-related, industrial, or mixed) as well as its importance for the local economy. Even more important, this risk assessment procedure was able to measure the impact of the outfalls on human health and the environment.
\end{abstract}

(c) 2012 Elsevier Ltd. All rights reserved.

\section{Introduction}

Wastewater management is a result of cultural, environmental, political and economic factors, among others. Submarine outfalls, encountered in the final step of the effluent treatment, are one of the most important sanitation infra-structures used nowadays, being almost inevitable that the chosen places for the final effluent disposal will be the sea and the estuaries.

For a variety of reasons, an outfall structure may lose its resistance, structural capacity, and/or operational capacity. This total or partial loss may take place at different speeds and be temporary or permanent. The project design should thus be able to assure that the structure will be reliable, functional, and operational. Consequently, values or target levels of these attributes should be specified in the

\footnotetext{
* Corresponding author. Tel.: +351965477175.

E-mail addresses: amendonca@lnec.pt (A. Mendonça), mlosada@ugr.es (M.Á. Losada), treis@lnec.pt (M.T. Reis), gneves@lnec.pt (M.G. Neves).
}

project design phase before the structure is actually built. Evidently, the construction and maintenance costs of the outfall as well as its use and exploitation depend on all of these factors.

The European Water Framework Directive (WFD, 2000/60/EC) developed the concept of Ecological Quality Status for the assessment of water masses and for the establishment of water quality objectives. The designing of submarine outfalls is not fully contemplated in some countries legislation. In the Portuguese legislation the WWTP are the ones that require an Environmental Impact assessment (EIA) (Decree-Law No.69/2000 of 3 May and Decree-Law No.197/2005 of 8 November). These studies can also be required by the financing entity or within the administrative framework process. Moreover, should be considered: Directive No.2006/7/CE, of the European Parliament and of the Council of 15 February 2006, concerning the management of bathing water quality or other specific local legislation.

The specification of target design levels of reliability, functionality, and operationality is far from trivial. Decisions regarding 
a submarine outfall project should be based on previous studies of the economic, social, and environmental impacts of the construction. However, when one or more of such studies are not available, engineers need guidelines that will help them specify these values in the project design phase. This makes it possible to compare project alternatives at different locations and select the one that is optimal.

Submarine outfall projects generally include specifications pertaining to the conception, design, construction, exploitation, maintenance, and repair of the outfall. Nevertheless, they rarely include a systematic assessment of risks. This signifies that the design methods used are essentially deterministic in nature. There is thus an urgent need for a risk management procedure, based on statistical methods that can account for randomness and uncertainty. Such a procedure would incorporate information and data concerning the failure probability outfalls and the possible consequences of a failure. The result would lead to a more cost-efficient project. For constructions such as breakwaters and coastal defence structures, recommendations (e.g. ROM 0.0, 2002) advise the use of probabilistic and optimization techniques and demonstrate how they can be applied (e.g. Burcharth, 2000; Oumeraci et al., 2001; Losada and Benedicto, 2005). For outfall/intake works (Simm and Cruickshank, 1998) presents a checklist of common risks mainly related to the construction phase, whereas (Figueira, 2008) describes examples of risks at the conceptual, design, construction, and operation stages.

The risk assessment method outlined in this paper specifies the probability that the outfall will fail or stop operating, and states the possible consequences of such a failure or stoppage. Accordingly, the safety, service, and exploitation requirements for the submarine outfall and each of its sections are defined in terms of reliability, functionality, and operationality parameters (see ROM 0.0, 2002). This risk assessment method was used to evaluate four Portuguese submarine outfalls, representing the most common types of structures, based on the type of effluent (industrial and urban) and their importance to the region in terms of tourism and municipal serviceability.

\section{Aim and scope of the paper}

This paper describes an engineering procedure for the specification of the requirements and target design levels of a submarine outfall in the project phase. The following sections describe submarine outfalls as well as the calculation procedure that can be used for this purpose. After defining the intrinsic nature of a submarine outfall, an explanation is given of how the outfall can be evaluated. The subsequent assessment of the structure's intrinsic nature provides recommended values for the following aspects of the outfall: minimum useful life, minimum operationality, average number of admissible technical breakdowns, and maximum duration of a stoppage mode. These values make it possible to identify the principal failure modes and limit states for an outfall and its sections. This procedure was then applied to four submarine outfalls along the Portuguese coast at Sines, Viana do Castelo, Guia, and Vale de Faro.

\section{Submarine outfalls}

An outfall can be defined as the set of hydraulic structures between dry land and the receiving water body (Fig. 1) through which waste effluent is finally discharged. An outfall consists of three components: (i) the onshore headwork (e.g. gravity or pumping basin); (ii) the feeder pipeline which conveys the effluent to the disposal area; (iii) the diffuser section where a set of ports releases and disperses the effluent into the environment so as to minimize any impairment to the quality of the receiving waters. Moreover, diffusers discharge the effluent either through port orifices on the wall of the diffuser (simple-port configuration) or through attached pipes (riser/port configuration) (Bleninger et al., 2002).

Submarine outfall diffusers are conduits with circular ports located along each side of the conduit, usually just above the pipe centerline. The sewage effluent is discharged from them in the form of round turbulent jets. Since the effluent is less dense than ocean water, it rises to the surface. In the receiving water body, the column effluent is diluted because of entrainment and grows in size as it rises. Depending on port, spacing, exit velocity, and water depth, jets may merge together before reaching the surface or some maximum height of rise (Bleninger et al., 2002).

In some cases, submarine outfalls have performed poorly because of maintenance problems and damage by winter storms as well as sailing and fishing vessels. Nevertheless, sound design, protective measures, and regular maintenance and monitoring programs can guarantee the efficient operation of these waste disposal systems. Important benefits of outfalls include their relatively low operating and maintenance costs. Another advantage is their ability to cope with seasonal variations in flow and to obtain a dilution that is generally sufficient to prevent negative effects stemming from the discharge of organic matter and nutrients coping with the European Water Framework Directive.

The main causes of outfall ruptures, leaks, or even destruction are wave action, flotation, and the impact of anchors and fishing gear from fishing or sailing vessels. Outfall leaks are also caused by seasonal changes in the seabottom profile which the pipeline cannot adapt to. Accordingly, such changes need to be continuously monitored. Surface current surveys for submarine outfall design should cover different climate conditions, focusing on the summer period when sea water activities are at their height and winter period when most storms occur (Roberts et al., 2010; Grace, 2009).

This study focused on four submarine outfalls as representative examples of the most common types of outfall along the Portuguese coast. This classification was based on their effluent (industrial or urban) and their social, economic, and environmental importance in the region. The risk assessment procedure applied was based on the target design levels specified for the outfalls,

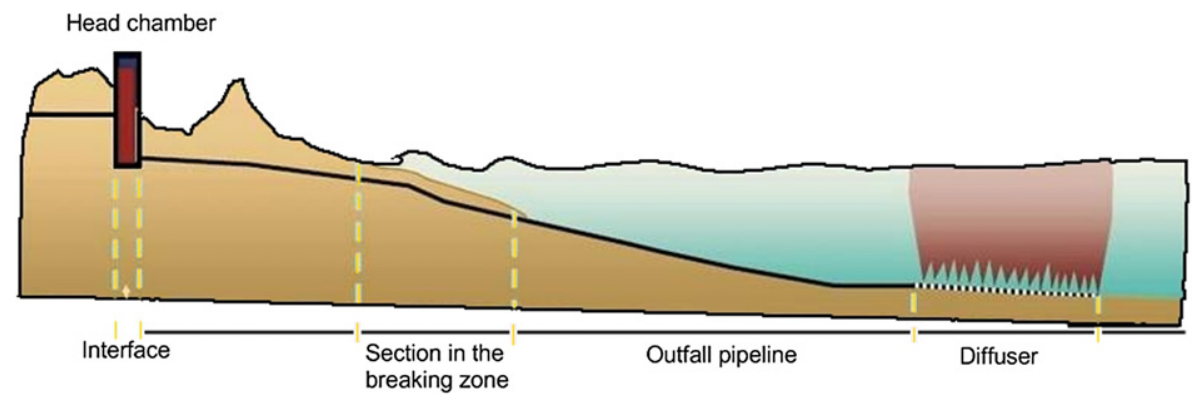

Fig. 1. Schematic layout of an outfall system. 


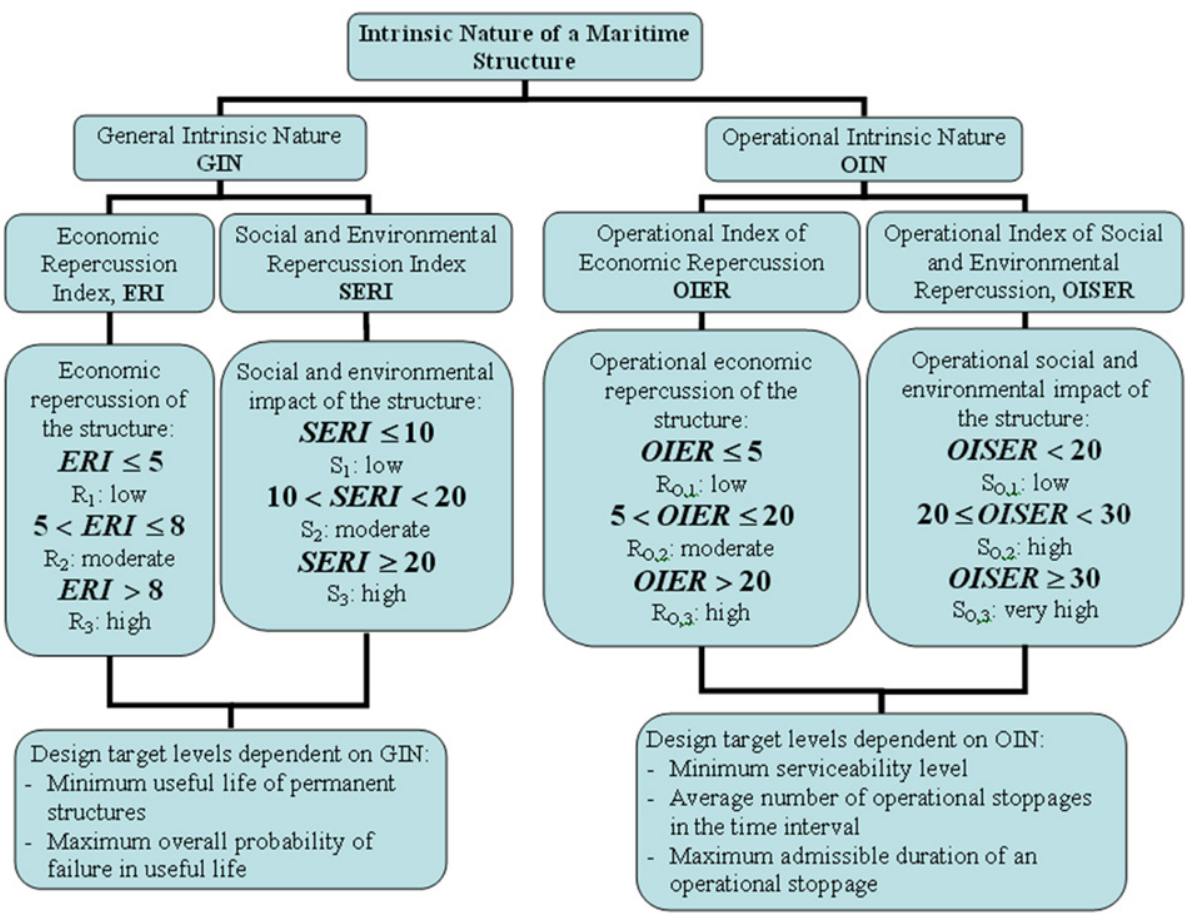

Fig. 2. Intrinsic nature of a submarine outfall [revised and adapted from the ROM 0.0 (2002)].

which were defined in terms of their general and operational intrinsic natures. These natures were used to quantify the importance of each structure in terms of the potential economic, social, and environmental impact in the event of serious damage, stoppage, or a total loss of functionality.

\section{Calculation procedure: specification of target design levels}

The procedure for calculating target design levels determines if a project satisfies the safety, serviceability, and exploitation requirements for the recommended levels of reliability, functionality, and operationality during all of the project phases (Losada and Benedicto, 2005). This procedure is composed of the following three steps (Fig. 2) ${ }^{1}$ :

(1) Evaluation of the indices of economic, social, and environmental repercussion, which define the general and operational intrinsic natures of the structure.

(2) Classification of the structure, based on the indices obtained in Step 1.

(3) Specification of the target design levels, based on the classification of the structure (Step 2). The identification of these design levels makes it possible to estimate the useful life of the structure, the joint probability of failure against the principal failure modes, minimum operationality, the average number of admissible technical breakdowns, and the maximum admissible duration of an operational stoppage (ROM 0.0, 2002).

\section{General and operational intrinsic nature}

The importance of a maritime structure or one of its sections as well as the economic, social, and environmental impact produced

\footnotetext{
1 The indices for submarine outfalls in the following sections are a revised and adapted version of the indices for maritime structures in the ROM 0.0
}

in the case of serious damage or destruction or total loss of service and functionality can be evaluated by means of the general intrinsic nature (GIN) of the structure or any of its sections (Fig. 2). The GIN is assessed by selecting the failure mode that gives the highest repercussion value from the principal modes assigned to the ultimate (ULS) and serviceability (SLS) limit states (ROM 0.0, 2002).

The general intrinsic nature of the structure is a function of the economic repercussion index (ERI) and the social and environmental repercussion index (SERI), which classify the structure in terms of two values $\left(R_{i}, S_{i}\right){ }^{2}$ The ensuing economic repercussions and the social and environmental repercussions when the maritime structure stops functioning or reduces its operational level are specified by its operational intrinsic nature (OIN). The OIN is evaluated by selecting the operational stoppage mode that gives the minimum operational level. It is then specified in terms of the operational index of economic repercussion (OIER) and the operational index of social and environmental repercussion (OISER). The structure is thus classified in terms of two values $\left(R_{O, i}, S_{O, i}\right)$.

\subsection{Economic repercussion index}

This Economic Repercussion Index (ERI) quantitatively assesses the economic repercussions of rebuilding the structure $\left(C_{\mathrm{RD}}\right)$ and the negative consequences for the economic activities related to the structure $\left(C_{\mathrm{RI}}\right)$ in the event that it is destroyed or can no longer be used (Fig. 3). The repercussions cost $\left(C_{\mathrm{RI}}\right)$ can be used to evaluate the economic repercussions that are the consequences of the economic activities directly related to the structure in the event of its destruction or total loss of exploitation capacity. These activities refer to services offered after the structure has begun to function as well as to services demanded because of damage to the goods being protected. The cost is valued in terms of loss of gross added value at

\footnotetext{
${ }^{2}$ In the absence of such a specification, the general intrinsic nature must be determined by the developer of the maritime structure.
} 


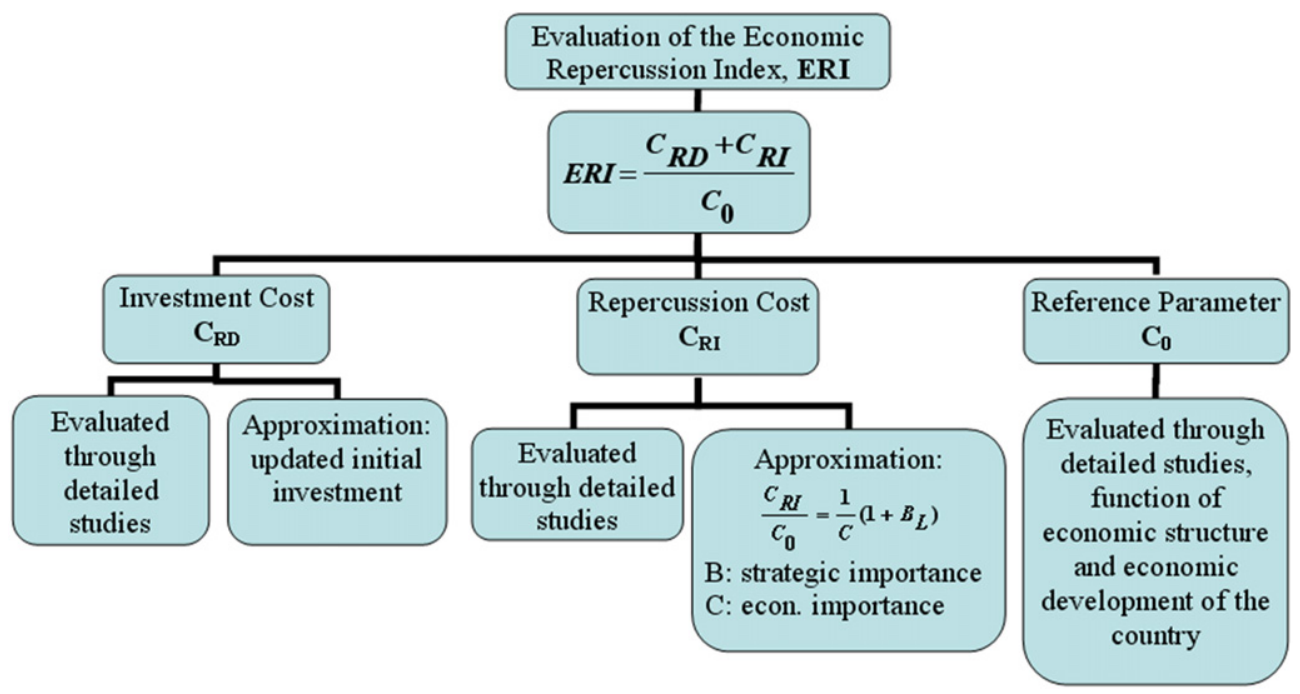

Fig. 3. Evaluation of the economic repercussion index [revised and adapted from the ROM 0.0 (2002) and Losada and Benedicto (2005)].

market prices during the time period that the rebuilding is supposed to take place after the destruction or loss of operationality of the structure. The cost is considered to occur once the economic activities directly related to the structure are consolidated (ROM 0.0, 2002; Losada and Benedicto, 2005). The ERI is defined by:

$\mathrm{ERI}=\frac{C_{\mathrm{RD}}+C_{\mathrm{RI}}}{C_{0}}$

in which $C_{0}$ is an economic parameter of dimensionalization. The value of this parameter depends on the economic structure and the level of economic development in the country where the structure will be built and consequently will vary over time. This value may be representative of the average unit investment cost per meter of a maritime structure in the country (Losada and Benedicto, 2005). Based on their ERI value, submarine outfalls can be classified in three groups $\left(R_{i}, i=1,2,3\right)$ :

- $R_{1}$ : structures with low economic repercussion: ERI $\leq 5$

- $R_{2}$ : structures with moderate economic repercussion: $5<$ ERI $\leq 8$

- $R_{3}$, structures with high economic repercussion: ERI $>8$

These scales are based on expert judgment and available information that characterizes the structure's importance (effluent volume, project flow, population served, population equivalent, interviews to local people, etc).

\subsubsection{Approximate evaluation of $C_{R I} / C_{0}$}

In those cases in which it is impossible to determine the $C_{\mathrm{RI}}$ because the structure is too large or because there is no information from previous studies (cost-benefit analysis [e.g. Castillo et al., 2004; Oumeraci et al., 2001] or socioeconomic optimization methods (CIRIA/CUR, 1991)), the value of the ERI can be qualitatively estimated as follows:

$\frac{C_{\mathrm{RI}}}{C_{0}}=\frac{1}{C}\left(1+B_{L}\right)$

This expression represents the relevance of submarine outfalls and their local strategic importance $\left(B_{L}\right)$ for the following: a1) Fishing and molluscs [Essential (5), Relevant (2), Irrelevant (0)]

a2) Environment: sensitive habitats, flora and fauna [Essential (5), Relevant (2), Irrelevant (0)]

a3) Tourism: beaches, nautical sports, etc. [Essential (5), Relevant (2), Irrelevant (0)]

C stands for the relevance of the outfall for the economic system, and the extent to which its structural damage/destruction will affect that system. The possible values of $C$ for submarine outfalls are: 3 (Relevant) or 2 (Essential).

The definition of the ecological status could be supported by indexes already presented in literature, as the Marine Biotic Index (AMBI) proposed by Borja et al. (2000) a to establish the ecological quality of soft-bottom benthos within European estuarine and coastal environments.

\subsection{Social and environmental repercussion index}

Submarine outfalls should guarantee the protection of aquatic ecosystems and enhance the status of these ecosystems by minimizing risks to human health and protecting the environmental value of the waters. Outfall project design should also consider the potential (direct or indirect) impact of the structure on food chain processes. According to the ROM 0.0 (2002), the Social and Environmental Repercussion Index (SERI) qualitatively assesses the social and environmental repercussions produced if the maritime structure is destroyed or can no longer operate. The factors evaluated are the following:

- $\mathrm{SERI}_{1}$ : impact on human health

- $\mathrm{SERI}_{2}$ : damage to the environment and habitats

- $\mathrm{SERI}_{3}$ : degree of social disruption when the failure occurs after the economic activities directly related to the structure have been consolidated

Based on their SERI values, submarine outfalls have been classified in three groups $\left(S_{i}, i=1,2,3\right)$ :

- $S_{1}$ : structures with low social and environmental impact, SERI $\leq 10$

- $S_{2}$ : structures with moderate social and environmental impact, $10<$ SERI $<20$ 
- $S_{3}$ : structures with high social and environmental impact, SERI $\geq 20$

\subsubsection{Approximate calculation of the SERI}

The SERI is defined as the sum total of the three subindices (ROM 0.0, 2002):

$\mathrm{SERI}=\sum_{i=1}^{3}$ SERI $_{i}$

Table 9 shows the subindex categories. The $\mathrm{SERI}_{1}$ is represented as:

$\mathrm{SERI}_{1}=\left[\sum_{i=1}^{3} a_{i}+B\right] C$

where:

- $a_{i}$ is the direct impact from bathing in contaminated waters and having contact with contaminated sand, potentially resulting in the following:

$a_{1}$ : skin irritations [Irrelevant (0), Relevant (1)]

$\bigcirc a_{2}$ : digestive problems [Irrelevant (0), Relevant (2)]

$\bigcirc a_{3}$ : chronic diseases [Irrelevant (0), Relevant (5)]

- $B$ is the indirect impact produced by the consumption of fish and molluscs [Irrelevant (0), Relevant (2)].

- $C$ is the sensitivity of the coastal area [Standard or Less Sensitive (1), Sensitive (2)].

In this respect, Portuguese law (i.e. Decreto-Lei n. ${ }^{\circ}$ 152/97) defines coastal zones as 'sensitive' or 'less sensitive'. The Algarve coast is included in the first category, whereas the rest of the coast is included in the second.

\subsection{Minimum useful life}

The duration of a structure's useful life $(V)$ should be at least the value in Table 1, based on the ERI of the submarine outfall. Table 1 shows the results obtained in the four case studies analysed. The useful life of the outfall is initially defined for the three classes of the ERI.

\subsection{Operational index of economic repercussion}

The operational index of economic repercussion (OIER) quantitatively assesses the costs resulting from the operational stoppage of the structure. The value of the OIER can be qualitatively estimated as shown in the next section. Based on their OIER value, submarine outfalls can be classified in three groups $\left(R_{O, i}, i=1,2,3\right)$ :

- $R_{O, 1}$ : structures with low economic repercussion (OIER $\leq 5$ )

- $R_{0,2}$ : structures with moderate economic repercussion $(5<$ OIER $\leq 20)$

- $R_{O, 3}$ : structures with high economic repercussion (OIER $>20$ )

Table 1

Minimum useful life.

\begin{tabular}{ll}
\hline Economic repercussion index & Useful life (years) \\
\hline ERI $\leq 5$ & $15 \leq \mathrm{V}<25$ \\
$5<$ ERI $\leq 8$ & $25 \leq \mathrm{V} \leq 50$ \\
$>8$ & $\mathrm{~V}>50$ \\
\hline
\end{tabular}

\subsubsection{Approximate calculation of the OIER}

The OIER is determined by the following formula (ROM 0.0 , 2002):

OIER $=F[D+E]$

where $D$ evaluates the simultaneity of the period of demand affected by the structure and the period of agent intensity defining the serviceability level; $E$ stands for the intensity of use in the time period; and $F$ refers to the adaptability of the demand and economic context to the operational stoppage. Evidently, if the demand can easily adapt to the stoppage, the economic repercussions of the stoppage are negligible (e.g. when a submarine outfall fails and the effluent can be stored or re-directed to another available submarine outfall). These coefficients can be determined with the values in Table 2 .

\subsection{Operational index of social and environmental repercussion}

The Operational Index of Social and Environmental Repercussion (OISER) qualitatively assesses the social and environmental repercussions in the event that the submarine outfall stops operating (Fig. 4). In most maritime structures, the OISER is zero since once an operational stoppage occurs, all possible causes of environmental impact also disappear. However, the stoppage of submarine outfalls can generate significant social and environmental repercussions. Submarine outfalls have been classified in three groups $\left(S_{O, i}, i=1,2,3\right)$ :

- $S_{O, 1}$ : structures with low social and environmental impact (OISER < 20)

- $S_{O, 2}$ : structures with high social and environmental impact $(20 \leq$ OISER $<30)$

- $S_{0,3}$ : structures with a very high social and environmental impact (OISER $\geq 30$ )

Table 2

Evaluation parameters for the operational index of economic repercussion.

\begin{tabular}{|c|c|c|c|c|c|}
\hline \multicolumn{2}{|l|}{$D$} & \multicolumn{2}{|l|}{$E$} & \multicolumn{2}{|l|}{$F$} \\
\hline Classification & Value & Classification & Value & Classification & Value \\
\hline $\begin{array}{l}\text { Non-simultaneous } \\
\text { periods }\end{array}$ & 0 & Not intensive & 0 & High & 0 \\
\hline $\begin{array}{l}\text { Semi-simultaneous } \\
\text { periods }\end{array}$ & 3 & Intensive & 3 & Moderate & 1 \\
\hline $\begin{array}{l}\text { Simultaneous } \\
\text { periods }\end{array}$ & 5 & Very intensive & 5 & Low & 3 \\
\hline
\end{tabular}

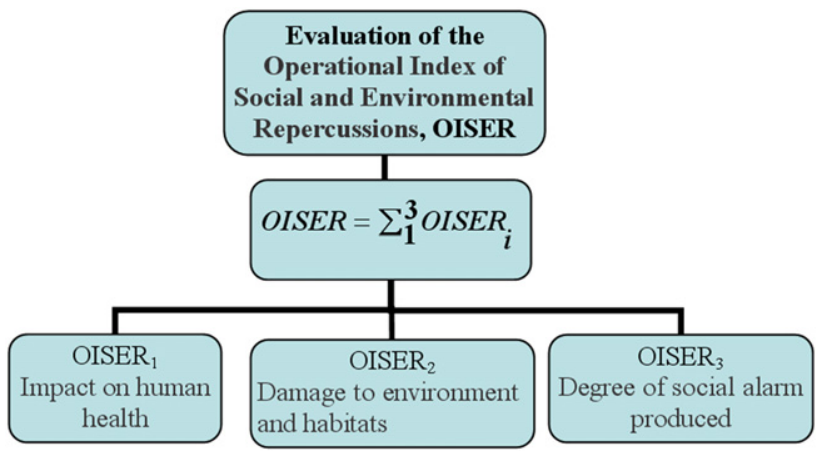

Fig. 4. Evaluation of the OISER [revised and adapted from the ROM 0.0 (2002) and Losada and Benedicto (2005)]. 


\subsubsection{Approximate calculation of the OISER}

For submarine outfalls, the OISER is defined by the sum total of the following three subindices (ROM 0.0, 2002):

$$
\text { OISER }=\sum_{i=1}^{3} \operatorname{OISER}_{i}
$$

Table 11 shows the evaluation of these subindices.

\subsection{Use and exploitation of a structure during its useful life}

The exploitation of any section of a structure can be defined in terms of the following: (i) minimum levels of operationality (in a specified time period based on previous economic studies); (ii) average number of stoppages (in a time interval linked to social and environmental factors): (iii) the maximum admissible duration of a stoppage in a time interval that depends on economic factors and the cycle of demand.

\subsubsection{Average number of stoppages}

In a given time interval (usually a year), and for those cases in which it has not already been specified, the average number of occurrences of all modes assigned to stoppage limit states $\left(N_{\text {stop }}\right)$ corresponds to the value shown in Table 3. If the operational stoppage has social and environmental repercussions $\left(S_{O, 3}\right)$, no stoppages must be allowed to occur. The submarine outfall should thus always be kept operational except in the event of extraordinary unforeseen conditions.

The main reasons that submarine outfalls stop operating are the obstruction of the pipe and diffuser, exceedance of the recommended limit values for the effluent discharge, and the use of a bypass. Bypasses can pose a direct health risk to people who come into contact with contaminated water. However, they can also indirectly affect people that consume contaminated seafood (e.g. shellfish). Such stoppages mostly occur in periods of heavy rain when the effluent exceeds the submarine outfall capacity. Information concerning bypasses can help to determine whether operations or maintenance practices need to be improved or if an upgrade of the submarine outfall is required. $N_{\text {stop }}$ can be evaluated as follows (Table 3):

$N_{\text {stop }}=\sum_{i=1}^{3} L_{i}$

where

- $L_{1}$ : Exceedance of limit values for the discharge

- $L_{2}$ : Obstruction of the pipe or diffuser

- $L_{3}$ : Bypass of the effluent due to overflow

\subsubsection{Maximum duration of stoppage}

During the structure's useful life (and when there are no previous specifications), the probable maximum duration of a stoppage (in hours) cannot exceed the value in Table 4, based on the OIER and OISER of the affected section of the structure.

Table 3

Parameters defining the average number of stoppages in the time interval.

\begin{tabular}{lllll}
\hline & $L_{1}$ & $L_{2}$ & $L_{3}$ & $N_{\text {stop }}=\sum_{i=1}^{3} L_{i}$ \\
\hline SERI $\leq 10$ & 8 & 1 & 3 & 12 \\
$10<$ SERI $<20$ & 4 & 1 & 2 & 7 \\
SERI $\geq 20$ & 2 & 1 & 1 & 4 \\
\hline
\end{tabular}

Table 4

Probable maximum duration of a stoppage mode (hours).

\begin{tabular}{|c|c|c|c|}
\hline \multirow{2}{*}{$\begin{array}{l}\text { Operational index } \\
\text { of economic } \\
\text { repercussion }\end{array}$} & \multicolumn{3}{|c|}{$\begin{array}{l}\text { Operational index of social and environmental } \\
\text { repercussion }\end{array}$} \\
\hline & OISER $<20$ & $20 \leq$ OISER $<30$ & OISER $\geq 30$ \\
\hline OIER $\leq 5$ & 24 & 12 & 6 \\
\hline $5<$ OIER $\leq 20$ & 12 & 6 & 3 \\
\hline OIER $>20$ & 8 & 4 & 2 \\
\hline
\end{tabular}

\section{Limit states and failure modes for submarine outfalls}

The procedure described in the ROM 0.0 (2002) specifies the overall probability of failure in the useful life of a maritime structure for all the principal modes ascribed to limit states. When principal failure and stoppage modes occur, there are evident consequences for the reliability, functionality, and operationality of the structure. Moreover, their probability of occurrence cannot be significantly reduced by increasing the construction cost and therefore improving the design. A comparative analysis of the increase in cost and expected reduction in the probability of failure must be performed to determine whether a failure mode is indeed a principal failure mode. The principal failure modes, and limit states for each section of a submarine outfall are the following:

- For the submerged pipe

1. Progressive collapse (ultimate limit state) caused by stress fluctuations in the pipeline due to direct wave action. These include vibrations of the pipe system, which may be due to vortex shedding (current, waves, wind, and towing) or fluid flow. Fluctuations may also be produced by movements of supporting structures, variations in operating pressure and temperature, or buoyancy due to liquefaction. Moreover, progressive collapse can be caused by vertical instability due to hydrodynamic forces resulting from the action of nearseabed, wave-induced, and steady currents on the pipe;

2. Fracture (ultimate limit state/serviceability limit state) caused by impacts from ship anchors, fishing trawlers, or any other sort of object;

3. Fatigue (serviceability limit state) associated with environmental loads (winds, waves, currents, earthquakes, etc.); Obstruction (serviceability limit state) caused by low effluent velocities, flows that exceed outfall capacity, sedimentation, and air entrapment because of curves in the pipe;

4. Internal corrosion (serviceability limit state/operationality limit state) caused by scaling, bacterial action, and non-selfcleaning velocities;

- For the diffuser

1. Fracture (ultimate limit state): caused by impacts associated with activities of outside parties: ship anchors, fishing operations, dropped object impacts, fishing trawlers;

2. Obstruction (serviceability limit state): marine growth, sea water intrusion, entrance of solids in low flow cycles, Corrosion (serviceability limit state/operationality limit state): by saline intrusion.

- For the riser

1. Fracture (ultimate limit state): dropped object impacts, environmental loads, pipe displacement or foundation settlement;

2. Obstruction (serviceability limit state) caused by marine growth, sea water intrusion, entrance of solids in low flow cycles, and trapped objects;

3. Corrosion (serviceability limit state/operationality limit state) caused by saline intrusion. 
- For the ring joints and anchor blocks

1. Fracture (serviceability limit state) caused by pipe displacement, overstressing, soil liquefaction, and vertical instability.

\subsection{Maximum safety and serviceability. Probability of failure}

The main objective of the methodology is to provide a set of standards and technical criteria for the design, construction, exploitation, maintenance, and repair of submarine outfalls.

The general procedure helps to determine if a project design alternative satisfies the safety, serviceability, and exploitation requirements in consonance with the recommended levels of reliability, functionality, and operationality during all of the project phases. Moreover the methodology can be applied to existing outfalls in the perspective of analyzing the structure's reliability, functionality, and operationality and possible mitigation measures.

In each project phase, the structure as a whole and each of its subsets, components, subcomponents, should meet the project requirements for safety, serviceability, and exploitation.

During a structure's useful life, the maximum overall probability of failure could be adjusted to the recommended values in Tables 5 and 6.

\subsubsection{Failure modes ascribed to ultimate limit states: safety requirements}

The minimum safety requirements for a submarine outfall (or any of its sections) within the context of the possible limit states in the serviceability phase are in direct relation to the consequences of the failure or the destruction of the structure. These consequences can be evaluated in terms of the general nature of the submarine outfall. The value obtained cannot be less than the value of the economic repercussion index (ERI) and the social and environmental repercussion index (SERI). In this sense, greater safety precautions should be taken when the social or environmental consequences of the breakage are more serious.

The maximum admissible failure probability of a submarine outfall within the context of all the possible failure modes ascribed to limit states $P_{\mathrm{f}}$, ULS, and the structure's corresponding useful life and return period $\left(T_{R}\right)$, should be less than the maximum values in Table 5 for the social and environmental repercussion index (SERI).

\subsubsection{Failure modes ascribed to serviceability limit states:} serviceability requirements

The minimum functionality of a submarine outfall (or each of its sections) within the context of the set of serviceability limit states

Table 5

Maximum overall probability of failure in the structure's useful life for ultimate limit states.

\begin{tabular}{llll}
\hline $\begin{array}{l}\text { Social and environmental } \\
\text { repercussion index }\end{array}$ & $P_{\mathrm{f}, \text { ULS }}$ & $V$ & $T_{\mathrm{R}}$ \\
\hline SERI $\leq 10$ & 0.1 & 25 & 240 \\
$10<$ SERI $<20$ & 0.1 & 50 & 475 \\
SERI $\geq 20$ & 0.05 & 50 & 975 \\
\hline
\end{tabular}

Table 6

Maximum overall probability of failure during the structure's useful life for serviceability limit states.

\begin{tabular}{llll}
\hline $\begin{array}{l}\text { Social and environmental } \\
\text { repercussion index }\end{array}$ & $P_{\mathrm{f}, \mathrm{SLS}}$ & $V$ & $T_{\mathrm{R}}$ \\
\hline SERI $\leq 10$ & 0.2 & 25 & 112 \\
$10<$ SERI $<20$ & 0.1 & 50 & 475 \\
SERI $\geq 20$ & 0.05 & 50 & 975 \\
\hline
\end{tabular}

that can arise during the structure's useful life is a function of the consequences of a serviceability failure. In regards to useful life, the structure's general nature evaluates these consequences. This general nature is specified in the same way as reliability, given that some of the failure modes ascribed to serviceability limit states may also entail repairing the structure in order to recover project design requirements. Similarly, the functionality or service capacity of the structure should be greater when the social and environmental consequences of failure are more important.

The joint probability of failure of a submarine outfall against the principal failure modes assigned to the serviceability limit states cannot exceed the values in Table 6 during the structure's useful life. Nonetheless, the recommended values of the joint probability of failure are purely indicative. Time and experience will eventually provide the necessary information to adjust these values.

\subsection{Minimum operationality}

\subsubsection{Requirements for operational stoppage modes}

The minimum operationality of a submarine outfall (or each of its sections) depends on the consequences of a stoppage within the context of the operational stoppage limit states that can arise during the serviceability phase, as well as the average number of stoppages and maximum duration of a stoppage. For the serviceability phase, the operational nature of the structure provides an overall evaluation of these consequences. The value, however, cannot be less than the value obtained for the operational index of economic repercussion (OIER) and the operational index of social and environmental repercussion (OISER). In this sense, the structure's operationality should be greater when the economic consequences of operational stoppage are more important. During its useful life, the operationality of the structure or one of its sections in reference to the principal modes assigned to the stoppage limit states in normal working and operating conditions has to be at least the value in Table 7 in accordance with the OIER.

\section{Case studies}

This research focused on four submarine outfalls located on the Portuguese coastline: (i) the Guia outfall in Cascais (Fig. 5b, c), which, serves four municipalities near Lisbon and which is the widest outfall in Portugal; (ii) the Sines outfall, the site of an important petrochemical industry; (iii) the Viana do Castelo outfall, which receives urban effluents as well as effluents from a paper industry; (iv) the Vale de Faro outfall, serving an important tourist resort area.

The case studies represent the most common types of submarine outfall in Portugal, based on the type of effluent (industrial and urban) and their importance to the region in terms of tourism and municipal serviceability (see Fig. 5 and Table 12). The Guia submarine outfall began operating in 1994. It is $2.8 \mathrm{~km}$ long and has a diameter of $1200 \mathrm{~mm}$. Located at a depth of $40 \mathrm{~m}$, it discharges approximately $170,000 \mathrm{~m}^{3}$ of urban effluent per day into the Atlantic Ocean. The structure has a V-shaped geometry with 80 ports in each diffuser. The system provides sanitation to about 720,000 inhabitants equivalent (I.E.) of four municipalities in the western area of Lisbon. The population of this region is expected to

Table 7

Minimum operationality in the useful life of the structure.

\begin{tabular}{ll}
\hline $\begin{array}{l}\text { Operational index of economic } \\
\text { repercussion }\end{array}$ & Operationality, $r_{\mathrm{f}, \text { ULS }}$ \\
\hline OIER $\leq 5$ & 0.90 \\
$5<$ OIER $\leq 20$ & 0.95 \\
OIER $>20$ & 0.99 \\
\hline
\end{tabular}



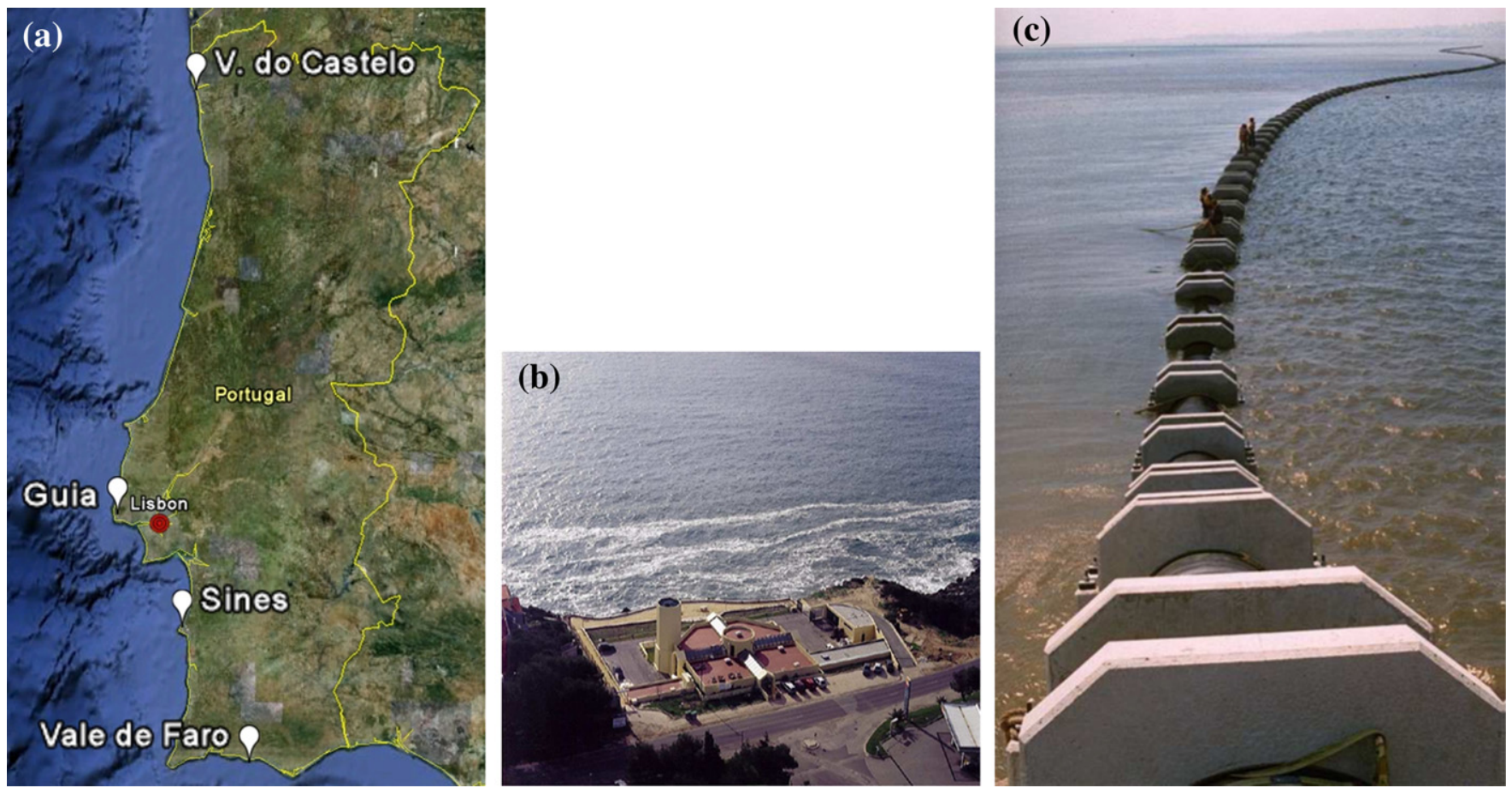

Fig. 5. (a) Submarine outfall location for the case studies; (b) Treatment plant of Guia, Cascais; (c) Submarine outfall of Guia.

reach 920,000 inhabitants in 2020, thus making it one of the largest submarine outfalls in Portugal. The urban wastewater undergoes preliminary treatment, which includes a step-screen to remove solids ( $<3 \mathrm{~mm}$ ) and grit removal prior to discharge (Santos et al., 2008; SANEST et al., 2009; Santos and Catarino, 2009).

The Sines outfall has been in service since 1978 and discharges approximately $11,535 \mathrm{~m}^{3}$ of industrial effluent (chemicals and refinery) and urban effluent per day. The system supplies sanitation to about 38,000 I.E. (urban), and the wastewater undergoes secondary treatment. The outfall is $2432 \mathrm{~m}$ long with a diameter of $1100 \mathrm{~mm}$, discharges the effluent from a depth of $38 \mathrm{~m}$ and the diffuser has 60 ports (Reis and Neves, 2003; Freire, 2006).

The Viana do Castelo outfall at Praia do Cabedelo corresponds to 20,000 I.E., and has been operating since 1973. Its effluent comes from a large paper industry, but it also discharges urban effluent with secondary treatment. The exploration flow is $3000 \mathrm{~m}^{3}$ per day. The outfall is $2250 \mathrm{~m}$ long with a diameter of $900 \mathrm{~mm}$ and discharges its effluent from a depth of $17.5 \mathrm{~m}$. The diffuser has 15 ports (Reis and Neves, 2003; Freire, 2006).
The Vale de Faro outfall has been operating since 1986 and is located in Praia do Inatel, Albufeira, an important tourist area with a floating population of 14,000 habitants in summer. The system supplies sanitation to about 130,000 I.E. In the summer, it receives urban effluent with secondary treatment, which has also been disinfected. The outfall is $956 \mathrm{~m}$ long with a diameter of $400 \mathrm{~mm}$ and discharges its effluent at a depth of $8 \mathrm{~m}$. The diffuser has 8 ports (WW, 2004).

The first step in our research study was to define the general and operational intrinsic natures of the outfalls and specify their target design levels. We thus used the general calculation procedure (see Section 4) to evaluate the indices of economic, social, and environmental repercussions (ERI and SERI) for each outfall. Table 8 shows the parameter values of the economic repercussion index (ERI) for each case study. These ERI values indicate that the economic repercussions of the destruction or total loss of exploitation capacity of the outfalls are low for Guia (ERI $\leq 5$ ); moderate for Viana do Castelo and Vale de Faro $(5<\mathrm{ERI} \leq 8)$; and high for Sines (ERI > 8).

Table 8

Parameter values of the economic repercussion index (ERI) for the case studies (source: Reis et al., 2004; Seth, 2010).

\begin{tabular}{|c|c|c|c|c|c|}
\hline Parameter definition & Parameter & Guia, Cascais & Sines & Viana do Castelo & Vale de Faro \\
\hline Updated investment cost $C_{\mathrm{RD}}$ (euros) & - & 880,000 & 600,000 & 250,000 & 240,000 \\
\hline Dimensionalization parameter, $C_{0}$ & - & 300,000 & 300,000 & 300,000 & 300,000 \\
\hline$C_{\mathrm{RD}} / C_{0}$ & - & 2.93 & 2.0 & 0.83 & 0.8 \\
\hline Coefficient of economic importance, $C$ & $\begin{array}{l}\text { 3: Relevant } \\
\text { 2: Essential }\end{array}$ & 3 & 2 & 2 & 2 \\
\hline Fishing/molluscs, $a_{1}$ & $\begin{array}{l}\text { 0: Irrelevant; } 2 \text { : Relevant } \\
\text { 5: Essential }\end{array}$ & 2 & 5 & 5 & 5 \\
\hline Tourism, $a_{2}$ & $\begin{array}{l}\text { 0: Irrelevant; } 2 \text { : Relevant } \\
\text { 5: Essential }\end{array}$ & 2 & 2 & 2 & 5 \\
\hline Environment and protected habitats, $a_{3}$ & $\begin{array}{l}\text { 0: Irrelevant; } 2 \text { : Relevant } \\
\text { 5: Essential }\end{array}$ & 0 & 5 & 5 & 0 \\
\hline Affected areas, $B_{L} \sum_{i=1}^{3} a_{i}$ & - & 4 & 12 & 12 & 10 \\
\hline$C_{\mathrm{RI}} / C_{0}=1 / C \times\left[1+B_{L}\right]$ & - & 1.67 & 6.5 & 6.5 & 5.5 \\
\hline ERI $C_{\mathrm{RD}} / C_{0}+C_{\mathrm{RI}} / C_{0}$ & - & 4.60 & 8.5 & 7.33 & 6.3 \\
\hline
\end{tabular}


Table 9

Parameter values of the social and environmental repercussion index (SERI) for the case studies.

\begin{tabular}{|c|c|c|c|c|c|}
\hline Parameter definition & Parameter & Guia, Cascais & Sines & Viana do Castelo & Vale de Faro \\
\hline Skin irritations $a_{1}$ & 0: Irrelevant; 1: Relevant & 1 & 1 & 1 & 1 \\
\hline Digestive problems $a_{2}$ & 0: Irrelevant; 2 : Relevant & 2 & 2 & 2 & 2 \\
\hline Chronic diseases $a_{3}$ & 0: Irrelevant; 5: Relevant & 0 & 5 & 5 & 0 \\
\hline $\begin{array}{l}\text { Indirect, ingestion of fish } \\
\text { and molluscs } B\end{array}$ & 0: Irrelevant; 2: Relevant & 0 & 2 & 2 & 2 \\
\hline Coastal area $C$ & 1: Standard; 2: Sensitive & 1 & 1 & 1 & 2 \\
\hline SERI $_{1}\left[\sum_{i=1}^{3} a_{i}+B\right] \times C$ & - & 3 & 10 & 10 & 10 \\
\hline $\mathrm{SERI}_{2}$ & $\begin{array}{l}\text { 0: Remote; 2: Low; 4: Moderate; } \\
\text { 8: High; 15: Very high }\end{array}$ & 2 & 4 & 4 & 2 \\
\hline $\mathrm{SERI}_{3}$ & $\begin{array}{l}\text { 0: Low; } 5 \text { : Moderate; 10: High; } \\
\text { 15: Very high }\end{array}$ & 5 & 10 & 5 & 5 \\
\hline SERI $\sum_{i=1}^{3} \mathrm{SERI}_{i}$ & - & 10 & 24 & 19 & 17 \\
\hline
\end{tabular}

Table 9 gives the parameter values of the social and environmental repercussion index (SERI) for the four submarine outfalls. These SERI values indicate that the social and environmental repercussions of the destruction or total loss of operationality of the outfalls are low for Guia (SERI $\leq 10)$; moderate for Viana do Castelo and Vale de Faro $(10<$ SERI $<20)$; and high for Sines (SERI $\geq 20$ ).

As part of this first step, it was also necessary to evaluate the indices of economic, social, and environmental repercussion (OIER and OISER). Our study found that the obstruction of the submarine outfalls was the stoppage mode that resulted in the minimum operational level. Table 10 shows the values of parameters $D, E$, and $F$, which were used to quantify the OIER.

- All of the outfalls operate non-stop year round. However, the period of agent intensity that defines the serviceability level (e.g. fracture due to direct wave action) occurs only at certain times, though mainly in winter. The simultaneity of the period of demand is thus $D=3$ (semi-simultaneous periods) in all cases;

- The intensity $(E)$ of use and demand in the case of Sines and Viana do Castelo, both of which are industrial and mixed submarine outfalls, is defined as very intense $(E=5)$. Since Guia receives urban effluent from four municipalities, it is considered intense $(E=3)$. Vale de Faro is not intense $(E=0)$ since its highest demand periods are limited to the summer months when the population increases.

- Adaptability is low for Sines and Viana do Castelo $(F=3)$. In both cases, there is only one submarine outfall available. Thus, if an operational stoppage occurred, the industries there would be obliged to shut down as well. In the case of Guia and Vale de Faro, adaptability is moderate $(F=1)$. If either of these outfalls suffered an operational stoppage, the effluent would continue to be discharged near the coastline. Moreover, since most failures occur in winter, the social, economic, and environmental repercussions would be much lower.

The values obtained for the OIER indicate a low economic repercussion for Vale de Faro (OIER $\leq 5$ ); a moderate economic repercussion for Guia $(5<$ OIER $\leq 20)$; and a high economic repercussion for Sines and Viana do Castelo (OIER $>20$ ).

Table 11 shows the parameter values used to quantify the OISER. The values indicate that the OISER of the submarine outfalls in the event of operational stoppage are low for Guia (OISER $<20$ ); high for Viana do Castelo and Vale de Faro $(20 \leq$ OISER $<30)$; and very high for Sines (OISER $\geq 30$ ). This evaluation highlights the importance of the submarine outfalls that deal with industrial effluents and their possible impacts on human health and the environment.

In the second step of this procedure, the four submarine outfalls were classified, based on the indices obtained in the first step. Since fracture is the worst failure mode ascribed to an ultimate limit state, the following conclusions can be derived:

- The economic repercussion is low for Guia $\left(R_{1}\right)$; moderate for Viana do Castelo and Vale de Faro $\left(R_{2}\right)$; and high for Sines $\left(R_{3}\right)$.

- The social and environmental impact is low for Guia $\left(S_{1}\right)$; moderate for Viana do Castelo and Vale de Faro $\left(S_{2}\right)$; and high for Sines $\left(S_{3}\right)$.

Table 10

Parameter values of the operational index of economic repercussion (OIER) for the case studies.

\begin{tabular}{|c|c|c|c|c|c|}
\hline Parameter definition & Parameter & Guia, Cascais & Sines & Viana do Castelo & Vale de Faro \\
\hline Simultaneity $D$ & $\begin{array}{l}\text { 0: Non-simultaneous periods } \\
3: \text { Semi-simultaneous periods } \\
5: \text { Simultaneous periods }\end{array}$ & 3 & 3 & 3 & 3 \\
\hline Intensity $E$ & $\begin{array}{l}0: \text { Not intensive } \\
3: \text { Intensive } \\
5: \text { Very intensive }\end{array}$ & 3 & 5 & 5 & 0 \\
\hline Adaptability $F$ & $\begin{array}{l}3: \text { Low } \\
1: \text { Moderate } \\
0: \text { High }\end{array}$ & 1 & 3 & 3 & 1 \\
\hline OIER $F[D+E]$ & - & 6 & 24 & 24 & 3 \\
\hline
\end{tabular}

Table 11

Parameter values of operational index of social and environmental repercussion (OISER) for the case studies.

\begin{tabular}{|c|c|c|c|c|c|}
\hline Parameter definition & Parameter & Guia, Cascais & Sines & Viana do Castelo & Vale de Faro \\
\hline Impact on human health OISER $_{1}$ & 3: Relevant; 10: High; 15: Very high; 20: Catastrophic & 3 & 15 & 10 & 10 \\
\hline Damage to environment and habitats OISER $_{2}$ & 2: Low; 4: Moderate; 8 : High; $15:$ Very high & 4 & 15 & 8 & 8 \\
\hline Degree of social alarm OISER $_{3}$ & 0: Low; $5:$ Moderate; 10: High; 15: Very high & 5 & 15 & 10 & 10 \\
\hline OISER $\sum_{i=1}^{3}$ OISER $_{i}$ & - & 12 & 45 & 28 & 28 \\
\hline
\end{tabular}


Table 12

Submarine outfall characteristics source: (Seth, 2010, Santos et al., 2011; Reis et al., 2004).

\begin{tabular}{|c|c|c|c|c|}
\hline Characteristics & Guia, Cascais & Sines & Viana do Castelo & Vale de Faro \\
\hline \multirow[t]{2}{*}{ Effluent type } & Urban & Industrial (chemical and refinery) + urban & Industrial (paper industry) & Urban \\
\hline & 1994 & 1976 & 1973 & 2005 \\
\hline Investment cost & & 550,000 & 250,000 & $3,512,305$ \\
\hline Treatment & $\begin{array}{l}\text { Preliminary. Disinfection } \\
\text { in summer season }\end{array}$ & Secondary & Secondary & Secondary + disinfection \\
\hline Pop Equiv. & 750,000 & $38,000+$ Industrial & 20,000 (urban) + industrial & 130,000 \\
\hline $\begin{array}{l}\text { Exploration flow }\left(\mathrm{m}^{3} / \text { day }\right) \\
\text { Project flow }\left(\mathrm{m}^{3} / \text { day }\right)\end{array}$ & 170,000 & 11,535 & 30,000 & \\
\hline Length $(\mathrm{m})$ & 3100 & 2480 & 2200 & 1020 \\
\hline Maximum depth $\mathrm{ZH}(\mathrm{m})$ & -41 & -38 & -17 & -11 \\
\hline Pipe diameter (mm) & 1200 & 1100 & 900 & 1000 \\
\hline Diffuser length (m) & 1800 & 240 & 100 & 160 \\
\hline Diffuser ports & $2 \times 80$ & 60 & 15 & 32 \\
\hline Outfall material & HDPE & Reinforced concrete (with steel) & Reinforced concrete (with steel) & HDPE \\
\hline
\end{tabular}

- When obstruction occurs, the economic repercussion is high for all four outfalls $\left(R_{O, 3}\right)$. In contrast, the social and environmental impact is low for Guia $\left(S_{O, 1}\right)$; high for Viana do Castelo and Vale de Faro $\left(S_{O, 2}\right)$; and very high for Sines $\left(S_{O, 3}\right)$.

\section{Conclusions}

This research study has described a risk assessment procedure for the project design phase of submarine outfalls. The methods and tools used account for randomness and uncertainty, and are also conducive to cost optimization. This paper outlines the initial steps of a procedure that facilitates decision-making in regards to the target design levels for submarine outfalls, whatever the materials, techniques, and elements used in their construction. This procedure is a revised and adapted version of the ROM 0.0 classification of maritime structures in terms of their general and operational intrinsic natures, based on various repercussion indices (ROM 0.0, 2002; Losada and Benedicto, 2005). These indices evaluate the economic, social, and environmental consequences of the most severe failure and stoppage modes.

This procedure was applied to four case studies of submarine outfalls located on the Portuguese coast. Based on the type of submarine outfall and its importance to economy, tourism, and the environment, values were obtained for the minimum useful life of the structure, the joint probability of failure against the principal failure modes, minimum operationality, average number of admissible technical breakdowns, and the maximum duration of a stoppage mode.

\section{Acknowledgments}

This study was funded by the Fundação para a Ciência e a Tecnologia, Portugal through PhD grant SFRH/BD/60748/2009, awarded to Ana Mendonça. The authors also gratefully acknowledge the technical support provided by WW - Consultores de Hidráulica e Obras Marítimas, S.A., Portugal.

\section{References}

Bleninger, T., Lipari, G., Jirka, G.H., 2002. Design and optimization program for internal diffuser hydraulics. In: 2nd International Conference on Marine Waste Water Discharges (MWWD 2002), Istanbul, September 16-20.
Borja, A., Franco, J., Pérez, V., 2000. A marine biotic index to establish the ecological quality of soft-bottom benthos within European estuarine and coastal environments. Marine Pollution Bulletin 40, 1100-1114.

Burcharth, H.F., 2000. Reliability Based Design of Coastal Structures. Coastal Engineering Research Center, Vicksburg, Mis.

Castillo, E., Losada, M.A., Mínguez, R., Castillo, C., Baquerizo, A., 2004. Optimal engineering design method that combines safety factors and failure probabilities: application to rubble-mound breakwaters. Journal of Waterway, Port, Coastal, and Ocean Engineering 130 (2), 77-88.

CIRIA/CUR, 1991. Manual on the Use of Rock in Coastal and Shoreline Protection. CIRIA Special Publication 83, London, UK, and CUR Publication 154, Gouda, The Netherlands CUR/RWS, 1995. Manual on the Use of Rock in Hydraulic Engineering. Publication 169 of CUR, Gouda, The Netherlands.

Figueira, P., 2008. Risk assessment in the construction of submarine outfalls and intakes. In: Proc. MWWD 2008, 5th International Conference on Marine Waste Water Disposal and Marine Environment, Dubrovnik, Croatia, October 27-31.

Freire, A., 2006. Campanha de Inspecções a ETAR com Descarga em Zonas Balneares Costeiras 2005. Relatório Técnico. Inspecção-Geral do Ambiente e do Ordenamento do Território, Lisboa, 49 pp.

Grace, R.A., 2009. Marine Outfall Construction Background, Techniques, and Case Studies. American Society of Civil Engineers. ISBN:10:0784409846(1991).

Losada, A.M., Benedicto, M.I., 2005. Target design levels for maritime structures. Journal of Waterway, Port, Coastal, and Ocean Engineering 131, 171-180.

Oumeraci, H., Kortenhaus, A., Allsop, W., de Groot, M., Crouch, R., Vrijling, H., Voortman, H., 2001. Probabilistic Design Tools for Vertical Breakwaters. Balkema Publishers, Amsterdam.

Reis, M.T., Neves, M.G., 2003. Comportamento estrutural de emissários submarinos. Abordagem metodológica. Relatório 24/03-NPE, Proc. 603/14/14053. LNEC, Lisboa, Portugal, 171 pp.

Reis, M.T., Neves, M.G., Silva, L.G., 2004. Emissários submarinos em Portugal. Recursos Hídricos, APRH 25 (3), 31-41.

Roberts, Philip J.W., Salas, Henry J., Reiff, Fred M., Libhaber, Menahem, Labbe, Alejandro, Thomson, James C., 2010. Marine Wastewater Outfalls and Treatment Systems. IWA Publishing, ISBN 9781843391890. Print.

ROM 0.0, 2002. General Procedure and Requirements in the Design of Harbor and Maritime Structures. Part I: Recommendations for Maritime Structures. Ministerio de Fomento, Puertos del Estado, Spain.

SANEST, CONSULGAL, SETH75, 2009. Empreitada de "inspecção e manutenção/ reparação do emissário submarino da Guia.

Santos, C., Catarino, J., Março 2009. Monitorização Ambiental do Emissário Submarino da Guia - Caracterização do Meio Receptor - 2008, Relatório Final. Relatório INETI/Cendes, $42 \mathrm{pp}+$ Anexos.

Santos, C., Catarino, J., Figueiredo, Z., Calisto, S., Cunha, P., Antunes, M., 2008. Water and wastewater monitoring of Guia submarine outfall - an 11 year survey. In: MWWD 2008-5th International Conference on Marine Waste Water Discharges and Coastal Environment. Cavtat (Dubrovnik, Croatia) - October 27-31.

Santos, C., Barreiros, A., Pestana, P., Cardoso, A., Freire, A., 2011. Environmental status of water and sediment around submarine outfalls - west coast of Portugal. Journal of Integrated Coastal Zone Management 11 (2), 207-217.

Seth, 2010. Emissário Submarino de Albufeira. WWTP, WTP and Marine Outfall Report

Simm, J., Cruickshank, I., 1998. Construction Risk in Coastal Engineering. Thomas Telford, London.

WW-Consultores de Hidráulica e Obras Marítimas, 2004. Empreitada de concepção-construção de reforço da etapa de desinfecção da ETAR de Vale de Faro, em Albufeira e das correspondentes infra-estruturas de rejeição no mar das águas residuais tratadas. Emissário Submarino. Projecto de Execução. 